\title{
The Effectiveness of a Learner-Centered Pedagogical Approach with Flipped Pedagogy and Digital Learning Environment in Higher Education Feedback on a Cell Biology Course
}

\author{
https://doi.org/10.3991/ijet.v16i12.19125 \\ Lynda Ouchaouka $\left({ }^{\bowtie}\right)$ \\ Laboratory of Engineering and Materials (LIMAT), Bengaluru, India \\ Hassan II University of Casablanca, Casablanca, Morocco \\ lynda.ouchaouka@gmail.com \\ Zineb Laouina, Mohamed Moussetad, Mohammed Talbi, \\ Najat Elamrani, M'hammed ElKouali \\ Hassan II University of Casablanca, Casablanca, Morocco
}

\begin{abstract}
This paper aims to examine the results of a survey of 292 firstyear biology students to evaluate their perception of their learning environment, as well as their ability to handle an educational innovation such as reverse pedagogy and serious gaming integrated into a hybrid learning environment. We also present the approaches and steps that allowed us to validate our statistical study. We used a methodology to validate the instrument developed; using standard parameters, the mean and the standard deviation to describe quantitative data and percentages for qualitative data. The internal consistency of the scales was assessed using the correlation coefficient calculated after a onefactor analysis of variance as well as Cronbach's alpha coefficient $(\alpha)$. The scores show that the items and subscales have good internal consistency. In addition, it shows that the students are fully aware of their learning environment and the difficulties they encounter. They are motivated to embrace our pedagogical innovation. It, therefore, confirms our willingness to implement this pedagogical model for students in the coming years.
\end{abstract}

Keywords - Higher education, flipped pedagogy, learner-centered approach, digital learning, measurement instrument, validation

\section{Introduction}

Flipped pedagogy is a fairly new concept, especially in higher education. In Moroccan universities, online education has been introduced into teaching practices since the 2000s (Conseil Supérieur de l'Éducation, 2015) [1], but it remains rather limited and dependent on the commitment of institutions and teachers.

Since 2009, the number of graduates has considerably increased in Morocco. The massification has been one of the obstacles to the success of the reform in Moroccan 
higher education. The reform had as the principal goal to reorganize the educational program, following the Bologna process (modular system Licence (bachelor) - Master - Doctorate, (LMD system). This massification doesn't allow establishing quality in Moroccan higher education (Instance Nationale d'Évaluation, 2014) [2].

The philosophy of the LMD system considers the students responsible for their training, their progression in their academic curriculum, according to their abilities and learning pace, the modularity of courses, and the capitalization of achievements until the realization of their personal and professional projects.

To uplift this reform, the Moroccan universities have paid particular attention to the linguistic deficit of new students in the courses taught in French, whereas, they have always studied in Arabic.

To this end, language and communication modules are delivered via the universities' Moodle platform in a hybrid system that addresses both the problem of massification and the diversity of levels among students. This technological innovation has pushed the Moroccan universities to reconsider university pedagogy towards active pedagogies such as flipped pedagogy (Lakrami, Labouidya and Elkamoun, 2018) [3]. This seems to be a relevant solution because it puts the learners in the center of the teaching/learning process as the main actors of their training and the development of their skills. The innovation has primarily affected practical works, which have been the most impacted by massification, online, virtual practical works, and simulations.

In our work, we would like to introduce a teaching model that combines flipped pedagogy and hybrid learning through a Learning Management System LMS for a module of Cell Biology, taught in the first year of the bachelor's degree in Life and Earth Sciences, we also aim at integrating the serious gaming concepts in this module. In general, the Cell Biology module is taught in all faculties of sciences in Morocco through lectures, tutorials and practical work, students receive all the theoretical part in lectures by the professors in charge of the module, exercises and practical tests are performed in reduced groups in classrooms and laboratories.

However, as we mentioned in a previous publication (L. Ouchaouka, et al, 2019) [4], the performance of this module is very low, just $11 \%$ of students validate it, and as it is a main module of the first academic year, it impacts the students' progress, and it remains a brake on their progress in the curriculum. For this reason, we have started this research project in order to introduce a multidimensional pedagogical innovation in the teaching of this module. This innovation deals with the introduction of reverse pedagogy and a serious game integrated into a hybrid teaching system.

The serious game is based on an overall pedagogical scenario of the course, it is realized with Unity 3D software, and it includes 3 levels: beginner, intermediate, and expert. It is adapted to the computer, tablet, and smartphone.

At the beginner level, the game is a diagnostic tool of the prerequisites of the students: the scores of this level will allow the learner to realize his gaps and to review the courses made available in the Moodle platform, the intermediate level aims to accompany the learner towards more difficult contents and to help him assimilate them by trial and error, the expert level allows the learners to discover new contents and to deepen their learning.

We decided to insert the serious game in a complete system including the module as shown in the figure1, it's role is to help the students in the most difficult parts of the course, For this, we have reconstructed the basic elements of the animal cell and 
we have built a game scenario that will allow the student/player to handle it and progress through the game by answering quizzes and questions from the course while playing, the game is immersive and it will help the learner to memorize more, and compensate for the lack of practical work by handling the cell organelles in 3D. The serious game is actually in the experimental testing phase.

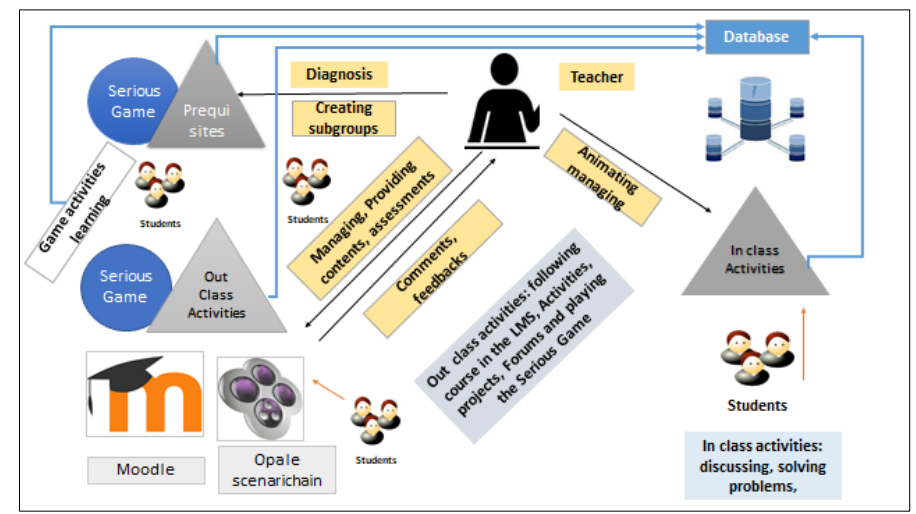

Fig. 1. The pedagogical model including the serious game (L. Ouchaouka, et al, 2019)

In this research work, we developed two questionnaires to assess the feasibility of our model with the main stakeholders of our project which are teachers and students involved in the first year of the bachelor's degree in Life and Earth Sciences of Ben M'sik Faculty of Sciences at Hassan II University in Casablanca particularly for the Cell Biology module.

The first questionnaire was addressed to the pedagogical team composed of 11 teacher-researchers; it shows their commitment to get involved in our model of teaching combining the flipped pedagogy with a serious game specially designed for the Cell Biology course.

In this article, we will analyze the results of the student questionnaire, in order to measure the relevance and the attractiveness of our model with the students we intend to involve in our experimentation in all phases of our pedagogical engineering from needs analysis, to design, development, implementation and evaluation.

\section{Background of The Study}

\subsection{Design of the study}

The study adopted a mixed method analysis using both quantitative and qualitative methods (Creswell) [3]. This study used a questionnaire of 6-parts in order to collect relevant data about the actual proposed learning model (lectures, tutorials, and practical works).

The questionnaire also aims at identifying the difficulties perceived by the students, as well as their commitment to a new model of active teaching/learning based on flipped classroom and new educational technologies with serious games [4]. 
To design this questionnaire, we have followed the succeeding steps to ensure that the results give the most accurate information possible [5]:

1. The formulation of the objectives of the questionnaire

2. The choice of sample design

3. The design of the questionnaire

4. The collection, processing and tabulation of data and the dissemination of the results.

In the design, we have taken care to minimize systematic errors (validity) and random errors (reliability) [6]. In the literature (Carmines E.G. Zeller R.A.1988) [7], the methods developed to test the validity of a study are very subjective, even if some have attempted to take on a more "scientific" dimension based on the principle of correlation. The latter do not resist certain theoretical weaknesses, and it is preferable to prefer explicitly subjective methods for choosing items in a questionnaire, such as expert consensus [8].

Evaluation methods have been developed under certain assumptions, to estimate a reliability coefficient. The Cronbach's alpha coefficient method is the most commonly used. However, it has been criticized for its correct design and the exact interpretation of the coefficient it calculates [9].

\subsection{Participants and experiment procedure}

292 students in the first year of the Life Sciences in the Faculty of Sciences Ben M'sik from Hassan II University of Casablanca (Morocco), responded to the questionnaire. This group is composed of 242 females $(83 \%)$ and 50 males $(17 \%)$, who have their baccalaureate of various streams: those who have a baccalaureate in Life and Earth Sciences represent the majority with a rate of $82 \%$, and those who have a Physical Sciences baccalaureate represent $18 \%$.

In order to study the relevance of introducing the concept of flipped pedagogy into the teaching/learning of the Cell Biology module, a questionnaire was addressed to the students of the 1 st year during the $1^{\text {st }}$ semester.

In terms of baccalaureate's degree grades, $42 \%$ of them had Third-class honors, $12 \%$ had lower second-class honors, $40 \%$ had Upper second-class honors and $6 \%$ had First-class honors.

The choice of the Life Sciences study field by the students was distributed as follows: $6 \%$ of students followed the advice of their parents, family, etc., $58 \%$ made a choice similar to that of their baccalaureate stream and $36 \%$ refrained from answering.

According to the language test carried out in French at the beginning of the academic year, $83 \%$ of the students obtained level A and $17 \%$ level $\mathrm{B}$, this test is conforming to the Common European Framework of Reference for Languages (CEFR) is the result of several years of linguistic research carried out by experts from the member states of the Council of Europe. This test is mandatory for new baccalaureate holders in all scientific fields in Moroccan universities because all scientific disciplines are taught in French. It makes it possible to provide reinforcement courses in 
languages according to levels (A, B, C), the French language module is delivered in hybrid via the LMS Moodle [10].

This questionnaire was conducted in French and Arabic and was distributed to the participants in a theatre during the teaching of the module subject of our study: Cell Biology. We presented the instructions to the students as well as the reasons for this survey. In order to answer any question, the questionnaire remained at their disposal for 45 minutes, and with the support of their teacher, we explained the different parts of the survey.

At the end, we collected the questionnaires and thanked the students. This survey took place in November 2019.

\subsection{Instrumentation and statistics}

This measurement instrument comprises 25 items divided into 6 sub-scales: (1) academic information, (2) teaching context, (3) learning barriers, (4) communication modalities, (5) digital learning environments, and (6) pedagogical innovation and integration of ICT. The answers were recorded according to a Likert-type scale with 8 points for (1), 3 points for (2), (3) and (5), 4 points for (4) and 4 points for (6).

A methodological approach was adopted to validate the instrument developed; using standard parameters (mean, standard deviation) to describe quantitative data and percentages for qualitative data. The internal consistency of the scales was assessed using the correlation coefficient calculated after a 1-factor analysis of variance as well as Cronbach's alpha coefficient $(\alpha)$ (Cronbach L.J., 1951). Statistical tests were twotailed with a significant threshold of $\mathrm{p}<0.05$. The Table 1 below provides a description of each of the subscales, and the number of items included in the subscales.

Table 1. Description of the subscales

\begin{tabular}{|l|l|l|c|}
\hline \multicolumn{1}{|c|}{ Sub scales } & \multicolumn{1}{|c|}{ Description } & $\begin{array}{l}\text { Number } \\
\text { of items }\end{array}$ \\
\hline (1) & Academic information & $\begin{array}{l}\text { Organization and understanding of the studies, prereq- } \\
\text { uisites, and main objectives }\end{array}$ & 8 \\
\hline (2) & Teaching context & The learning environment and its impact on the course & 3 \\
\hline (3) & Learning barriers & The difficulties identified in this course & 3 \\
\hline (4) & Communication modalities & The means of communication with teachers & 4 \\
\hline (5) & Digital learning environments & $\begin{array}{l}\text { The use of computers and social media for educational } \\
\text { purposes and access to the Internet }\end{array}$ & 3 \\
\hline (6) & $\begin{array}{l}\text { Pedagogical innovation and integra- } \\
\text { tion of ICT }\end{array}$ & $\begin{array}{l}\text { The use of ICT, knowledge of flipped pedagogy and } \\
\text { serious games }\end{array}$ & 5 \\
\hline
\end{tabular}

\section{$3 \quad$ Main Results and Discussion}

\subsection{Descriptive analysis}

The results of the descriptive analysis for each of the items have been grouped in Table 2. First, the mean (M) and standard deviation (SD) have been examined. 
The mean score for the 'Academic Information' subscale is 3.72 with a standard deviation of 0.97. 3.59, for 'Educational Context' with a standard deviation of 0.99, 4.11 for 'Learning Barriers' with a standard deviation of 0.96, and 3, 61 for 'Communication Modalities' with a standard deviation of 0.76, 4.32 for 'Digital Learning Environments' with a standard deviation of 0.91 and 4.43 for 'Pedagogical Innovation and Integration of ICT' with a standard deviation of 0.79 .

It can be observed that all items are practically similar in terms of mean and standard deviation. This finding led us to further analyze the data collected with this number of items.

Table 2. Statistical analysis of all items

\begin{tabular}{|c|c|c|c|}
\hline & \multicolumn{2}{|c|}{ Valid sample } & \\
\hline & \multicolumn{3}{|c|}{$n=292$} \\
\hline & $M$ & $E T$ & $\% \operatorname{Var}$ \\
\hline $\begin{array}{l}\text { Items of the subscale "Academic information" } \\
\text { (1) Are the objectives of the course explained? } \\
\text { (2) How clear are the lecture and tutorial sessions? } \\
\text { (3) Are the teacher's instructions clear? } \\
\text { (4) Are the course materials sufficient? } \\
\text { (5) Is the information presented clear? } \\
\text { (6) The duration of the course and Tutorial Sessions are quite sufficient? } \\
\text { (7) Are you directed to other resources? } \\
\text { (8) Are you informed about the testing procedures? } \\
\text { Total Score }\end{array}$ & $\begin{array}{l}4,09 \\
3,71 \\
4,04 \\
3,52 \\
3,94 \\
3,75 \\
3,18 \\
3,51 \\
\mathbf{3 , 7 2}\end{array}$ & $\begin{array}{l}0,93 \\
0,91 \\
0,92 \\
1,05 \\
1,05 \\
1,02 \\
0,90 \\
0,95 \\
\mathbf{0 , 9 7}\end{array}$ & $\begin{array}{c}30 \% \\
0 \% \\
9 \% \\
8 \% \\
7 \% \\
0 \% \\
43 \% \\
3 \% \\
\mathbf{1 0 0 \%} \\
\end{array}$ \\
\hline $\begin{array}{l}\text { Items of the subscale "Teaching context." } \\
\text { (1) Teaching spaces: adequate } \\
\text { (2) Teaching material: available } \\
\text { (3) Time slots adapted to the courses } \\
\text { Total Score }\end{array}$ & $\begin{array}{l}3,44 \\
3,42 \\
3,92 \\
\mathbf{3 , 5 9}\end{array}$ & $\begin{array}{l}0,94 \\
1,01 \\
1,04 \\
\mathbf{0 , 9 9}\end{array}$ & $\begin{array}{c}9 \% \\
25 \% \\
65 \% \\
\mathbf{1 0 0 \%} \\
\end{array}$ \\
\hline $\begin{array}{l}\text { Items of the subscale "Learning barriers." } \\
\text { (1) Language of teaching } \\
\text { (2) The lacking prerequisites } \\
\text { (3) The concepts are not easily assimilated } \\
\text { Total Score }\end{array}$ & $\begin{array}{l}4,20 \\
3,90 \\
4,23 \\
\mathbf{4 , 1 1} \\
\end{array}$ & $\begin{array}{l}0,96 \\
0,97 \\
0,94 \\
\mathbf{0 , 9 6} \\
\end{array}$ & $\begin{array}{c}14 \% \\
66 \% \\
20 \% \\
\mathbf{1 0 0 \%} \\
\end{array}$ \\
\hline $\begin{array}{l}\text { Items of the subscale "Communication modalities" } \\
\text { (1) Scoreboard } \\
\text { (2) Faculty website } \\
\text { (3) Facebook } \\
\text { (4) Internet } \\
\text { Total Score } \\
\end{array}$ & $\begin{array}{l}4,53 \\
3,48 \\
3,18 \\
3,23 \\
\mathbf{3 , 6 1}\end{array}$ & $\begin{array}{l}0,81 \\
0,83 \\
0,66 \\
0,73 \\
\mathbf{0 , 7 6}\end{array}$ & $\begin{array}{c}72 \% \\
1 \% \\
14 \% \\
12 \% \\
\mathbf{1 0 0 \%} \\
\end{array}$ \\
\hline $\begin{array}{l}\text { Items of the subscale "Digital Learning Environments" } \\
\text { (1) Are you used to using a computer? } \\
\text { (2) Do you have an internet connection? } \\
\text { (3) Have you ever used videos on YouTube to study? } \\
\text { Total Score }\end{array}$ & $\begin{array}{l}3,72 \\
4,65 \\
4,58 \\
\mathbf{4 , 3 2} \\
\end{array}$ & $\begin{array}{l}1,23 \\
0,71 \\
0,78 \\
\mathbf{0 , 9 1} \\
\end{array}$ & $\begin{array}{c}66 \% \\
20 \% \\
13 \% \\
\mathbf{1 0 0 \%} \\
\end{array}$ \\
\hline $\begin{array}{l}\text { Items of the subscale "Pedagogical innovation and integration of ICT" } \\
\text { (1) Would you like to receive the courses in advance? } \\
\text { (2) Do you use the internet for your documentary research? } \\
\text { (3) What do you think of the use of ICT in this course? } \\
\text { (4) Do you know about serious games } \\
\text { Total Score }\end{array}$ & $\begin{array}{l}4,90 \\
4,55 \\
4,59 \\
3,67 \\
\mathbf{4 , 4 3}\end{array}$ & $\begin{array}{l}0,52 \\
0,75 \\
0,86 \\
0,99 \\
\mathbf{0 , 7 9}\end{array}$ & $\begin{array}{c}26 \% \\
3 \% \\
0 \% \\
70 \\
\mathbf{1 0 0 \%} \\
\end{array}$ \\
\hline
\end{tabular}




\subsection{Analysis of variances}

In order to study the homogeneity of the obtained results, an analysis of the distribution was first performed based on the flattening coefficient (Kurtosis) and then a single-factor analysis of variance (ANOVA) was performed. According to Table 3, with the exception of items (1), (3) and (4) for communication modalities and (1) and (3) for pedagogical innovation and integration of ICT, which justifies the different proportions of variances recorded for the said components (Table 2). Contrary to these exceptions, all items follow a normal law. As for the total scores, they are distributed normally.

Table 3. Results of the normality test using the flattening coefficient (Kurtosis)

\begin{tabular}{|l|c|c|c|c|c|c|c|c|c|}
\hline \multicolumn{1}{|c|}{ Items } & $\mathbf{( 1 )}$ & $\mathbf{( 2 )}$ & $\mathbf{( 3 )}$ & $\mathbf{( 4 )}$ & $\mathbf{( 5 )}$ & $\mathbf{( 6 )}$ & $\mathbf{( 7 )}$ & $\mathbf{( 8 )}$ & $\begin{array}{c}\text { Total } \\
\text { Score }\end{array}$ \\
\hline Academic information & 1,35 & $-0,89$ & $-0,23$ & $-0,80$ & 0,26 & $-0,98$ & 0,71 & $-0,72$ & $\mathbf{- 0 , 1 9}$ \\
\hline Teaching context & $-0,45$ & $-0,58$ & $-1,21$ & & & & & & $\mathbf{1 , 0 5}$ \\
\hline Learning barriers & 0,08 & $-1,02$ & 0,05 & & & & & & $\mathbf{- 1 , 0 5}$ \\
\hline Communication modalities & 3,66 & $-0,40$ & 3,94 & 2,42 & & & & & $\mathbf{1 , 9 7}$ \\
\hline Digital learning environments & $-0,67$ & 2,73 & 0,90 & & & & & & $\mathbf{0 , 2 6}$ \\
\hline $\begin{array}{l}\text { Pedagogical innovation and } \\
\text { integration of ICT }\end{array}$ & 47,38 & 1,72 & 5,88 & $-1,28$ & & & & & $\mathbf{1 , 2 3}$ \\
\hline
\end{tabular}

The Table 4 shows the results of the analysis of variances of the total score and the analysis of variances of the subscales. According to these results we can see that $\mathrm{F}$ Observed $>$ F Critical but with a p-value probability $<0.01$, so we can see that the answers to the questions of all the items are homogeneous.

Table 4. Results of the analysis of variance (ANOVA) of the different sub-scales.

\begin{tabular}{|l|c|c|c|c|}
\hline \multicolumn{1}{|c|}{ Subscales } & ddl & F observed & P-value & F critical \\
\hline Academic information & 7 & 28,63 & $4,95 \mathrm{E}-38$ & 2,01 \\
\hline Teaching context & 2 & 31,21 & $1,52 \mathrm{E}-10$ & 3,01 \\
\hline Learning barriers & 2 & 10,26 & $3,95 \mathrm{E}-05$ & 3,01 \\
\hline Communication modalities & 3 & 201,62 & $3,29 \mathrm{E}-104$ & 2,61 \\
\hline Digital learning environments & 2 & 84,46 & $3,40 \mathrm{E}-34$ & 3,01 \\
\hline Pedagogical innovation and integration of ICT & 3 & 127,71 & $2,80 \mathrm{E}-71$ & 2,61 \\
\hline Score total & $\mathbf{5}$ & $\mathbf{2 2 3 9 , 6 2}$ & $\mathbf{0}$ & $\mathbf{2 , 2 2}$ \\
\hline
\end{tabular}

\subsection{The correlation matrix}

The assessment of the correlation between the items of each factor was carried out using the correlation coefficient. These are grouped in Table 5, using a threshold of 0.3 to help interpret the results. These results reveal that for the subscale 'academic information' there is a fair correlation between the component 'course objectives are explained' with 'are the teacher's instructions clear' (0.32) and 'are the course materials sufficient' (0.30). For the subscale 'teaching context' only the component 'teaching premises: adequate' correlates with 'teaching materials: available' $(0.31)$. In the sub- 
scale "learning barriers" there is a correlation only between the two components "missing pre-requisites" and "concepts are difficult to assimilate" (0.36). For the subscale "communication modalities", there is a correlation between the component "Facebook" and the component "internet" (0.44). A correlation between the two components 'would you like to receive the courses in advance' and 'what do you think of the use of ICT in this course' in the subscale 'pedagogical innovation and integration of ICT' was observed (0.44). No significant correlation is recorded neither between the components of the subscale 'digital learning environments' nor between the subscales. According to these results, most of the items of the same subscale do not correlate with each other; the same was true for the correlation between subscales.

Table 5. Correlation results between items and sub-scales.

\begin{tabular}{|c|c|c|c|c|c|c|c|c|}
\hline Academic Information & (1) & (2) & (3) & (4) & (5) & (6) & (7) & (8) \\
\hline (1) & 1 & & & & & & & \\
\hline (2) & 0,21 & 1 & & & & & & \\
\hline (3) & 0,32 & 0,27 & 1 & & & & & \\
\hline (4) & 0,08 & 0,13 & 0,30 & 1 & & & & \\
\hline$(5)$ & 0,19 & 0,20 & 0,23 & 0,24 & 1 & & & \\
\hline (6) & $-0,01$ & 0,23 & $-0,04$ & 0,04 & 0,07 & 1 & & \\
\hline (7) & $-0,12$ & 0,16 & $-0,03$ & 0,23 & 0,15 & 0,05 & 1 & \\
\hline$(8)$ & 0,00 & $-0,03$ & 0,05 & 0,15 & 0,09 & $-0,13$ & 0,04 & 1 \\
\hline Learning Context & \multicolumn{2}{|c|}{1} & \multicolumn{3}{|c|}{2} & \multicolumn{3}{|c|}{3} \\
\hline 1 & \multicolumn{2}{|c|}{1} & & & & & & \\
\hline 2 & \multicolumn{2}{|c|}{0,31} & \multicolumn{3}{|c|}{1} & & & \\
\hline 3 & \multicolumn{2}{|c|}{0,12} & \multicolumn{3}{|c|}{0,12} & \multicolumn{3}{|c|}{1} \\
\hline Learning barriers & \multicolumn{2}{|c|}{1} & \multicolumn{3}{|c|}{2} & \multicolumn{3}{|c|}{3} \\
\hline 1 & \multicolumn{2}{|c|}{1} & & & & & & \\
\hline 2 & \multicolumn{2}{|c|}{0,06} & \multicolumn{3}{|c|}{1} & & & \\
\hline 3 & \multicolumn{2}{|c|}{0,29} & \multicolumn{3}{|c|}{0,36} & \multicolumn{3}{|c|}{1} \\
\hline Communication modalities & \multicolumn{2}{|c|}{1} & \multicolumn{2}{|c|}{2} & 3 & & 4 & \\
\hline 1 & \multicolumn{2}{|c|}{1} & & & & & & \\
\hline 2 & \multicolumn{2}{|c|}{$-0,10$} & \multicolumn{2}{|c|}{1} & & & & \\
\hline 3 & \multicolumn{2}{|c|}{0,06} & \multicolumn{2}{|c|}{0,08} & 1 & & & \\
\hline 4 & \multicolumn{2}{|c|}{0,17} & \multicolumn{2}{|c|}{$\frac{0,08}{0,10}$} & 0,44 & \multicolumn{3}{|c|}{1} \\
\hline Digital learning Environments & & & \multicolumn{3}{|r|}{0,44} & & 3 & \\
\hline 1 & & & & & & & & \\
\hline 2 & & & & 1 & & & & \\
\hline 3 & & & & 0,26 & & & 1 & \\
\hline $\begin{array}{l}\text { Pedagogical innovation and } \\
\text { integration of ICT }\end{array}$ & & & & & 3 & & 4 & \\
\hline 1 & & & & & & & & \\
\hline 2 & & & & & & & & \\
\hline 3 & & & & & 1 & & & \\
\hline 4 & & & & & $-0,12$ & & 1 & \\
\hline
\end{tabular}




\subsection{Internal coherence}

In order to assess the internal structure of the questionnaire, a reliability analysis was carried out using Cronbach's alpha coefficient $(\alpha)$. The results of the test are represented in Table 6 which contains the values of the coefficient $(\alpha)$ before and after exclusion of certain items responsible for a decrease in its value, if any. Since there is no reliability threshold that allows an item to be retained or rejected from a subscale, and based on the literature (Huart, 2006) [11], (Nunally 1978)] [12] a threshold of 0.7 was used.

Table 6. Results of reliability analysis (Cronbach's alphas) for each of the subscales of the study measurement instrument.

\begin{tabular}{|l|c|c|c|c|}
\hline \multirow{2}{*}{} & \multicolumn{2}{|c|}{ Initial status } & \multicolumn{2}{c|}{ Final status } \\
\cline { 2 - 5 } & $\begin{array}{c}\text { Alpha's } \\
\text { Cronbach }\end{array}$ & $\begin{array}{c}\text { Number of } \\
\text { items }\end{array}$ & $\begin{array}{c}\text { Alpha's } \\
\text { Cronbach }\end{array}$ & $\begin{array}{c}\text { Number of } \\
\text { items }\end{array}$ \\
\hline Academic information & 0,55 & 8 & 0,84 & 6 \\
\hline Teaching context & 0,61 & 3 & 0,61 & 3 \\
\hline Learning barriers & 0,55 & 3 & 0,55 & 3 \\
\hline Communication modalities & 0,88 & 4 & 0,88 & 4 \\
\hline Digital learning environments & 0,84 & 3 & 0,84 & 3 \\
\hline Pedagogical innovation and integration of ICT & 0,58 & 4 & 0,72 & 3 \\
\hline Average score & $\mathbf{0 , 6 6}$ & $\mathbf{2 5}$ & $\mathbf{0 , 7 4}$ & $\mathbf{2 2}$ \\
\hline
\end{tabular}

According to the obtained results, for the 'academic information' subscale, only a coefficient of 0.55 ( 8 items) was obtained, the exclusion of two items contributes to the increase of Cronbach's alpha coefficient to 0.84 (6 items) by achieving a good internal consistency. For the 'teaching context' subscale, the coefficient of 0.61 (3 items) was below the selected threshold since the exclusion of no item allowed it to increase. Consequently, this subscale cannot be retained because it represents insufficient internal consistency.

The same applies to the 'learning barriers' subscale, which has a Cronbach's alpha coefficient value of 0.55 ( 3 items). On the other hand, the two subscales 'communication modalities' and 'digital learning environments' reflect excellent internal consistency with values of 0.88 ( 4 items) and 0.84 ( 3 items), consecutively. Concerning the subscale 'Pedagogical innovation and integration of ICT' (4 items) its alpha coefficient does not reach the minimum threshold; the increase of this coefficient was made by excluding one item to have a value of 0.72 ( 3 items).

In general, it can be noted that the questionnaire was validated by presenting an internal coherence reaching the threshold of Cronbach's alpha coefficient with a value of 0.74 ( 22 items).

The target population of our study is a community of new students, who are "natives" from the z-generation, which explains why they are familiar with issues related to communication modes and digital environments they were able to name their needs and note the weaknesses of the university system in which they are studying.

For questions related to teaching context and learning barriers, it seems difficult to capture the perception of students who are discovering a new environment and an 
educational system that is not familiar to them. As the questionnaire was administered during the 10th week of the semester, the students had difficulty deciding on questions of differentiation between lectures and tutorials that are new to them and whose limits are not very clear. For learning obstacles, the module is based on pre-requisites and at the period of our survey, the difficult passages of the module had not been addressed.

Concerning the pedagogical innovation, flipped pedagogy, and serious games subscale, the concepts are unknown and the responses demonstrated this, which has prevented us from considering these items.

\section{Conclusion}

In the present work, the questionnaire has been designed, to investigate the feasibility and relevance of introducing the concept of flipped pedagogy with a hybrid learning in the teaching/learning with students involved in the first year of university in the field of Life Sciences for the Cell Biology module.

It enabled us to put the most important stakeholder at the heart of our research project, which is the student. To realize, after 10 weeks of classes in a new learning environment, with new teaching methods, to gather their perceptions of university studies and the difficulties encountered as well as the opportunities that may arise to enable them to envisage training courses that will be able to trace their academic and then professional future. For our next surveys, we will refine the questions according to the data cited above and another questionnaire will be administered to this group at the end of the Bachelor's degree course (the third year of the academic curriculum). We want to make available to them the pedagogical model designed as well as the serious game in order to evaluate the contribution and the impact on the same group of students.

It should be noted that efforts need to be made to improve communication with students on the academic contents, evaluation methods, and prerequisites of each module. New technologies are familiar to the z-generation and using them at the university would make teaching more efficient and attractive.

The results of this study, which have been validated as shown earlier thanks to the statistical methods used, have enabled us to highlight the obstacles encountered by students in terms of the language of teaching, the prerequisites, and finally the desire to integrate new technologies into the teaching of this module. In the continuation of our work, we will put into practice our model combining flipped pedagogy, new technologies, and a serious game specially designed for this module.

\section{$5 \quad$ References}

[1] Conseil Supérier de l'Éducation, d. 1. (2015). Vision Stratégique 2015-2030.

[2] Instance Nationale d'Évaluation, C.S. (2014). Rapport Analytique. La mise enœuvre de la Charte Nationale d'Éducation et de Formation 2000-2013: Acquis, déficits et défis.

[3] Fatima Lakrami, Ouidad Labouidya et Najib Elkamoun, « Pédagogie universitaire et classe inversée: vers un apprentissage fructueux en travaux pratiques », Revue internationale de 
Paper-The Effectiveness of a Learner-Centered Pedagogical Approach with Flipped Pedagogy and Dig...

pédagogie de l'enseignement supérieur [En ligne], 34(3)| 2018, https://doi.org/10.4000/ripes.1793

[4] Ouchaouka L., Talbi M., Moussetad M., El Amrani N., Labriji L. (2020) Flipped Classroom and Serious Games as a New Learning Model in Experimental Sciences at the University. In: Auer M., Hortsch H., Sethakul P. (eds) The Impact of the 4th Industrial Revolution on Engineering Education. ICL 2019. Advances in Intelligent Systems and Computing, vol 1134. Springer, Cham. https://doi.org/10.1007/978-3-030-40274-7_69

[5] Jacques, Sebastien \& Lequeu, Thierry. (2020). The Attractiveness of Reversing Teaching Forms - Feedback on an Electrical Engineering Course. International Journal of Engineering Pedagogy (iJEP). 10. 21. https://doi.org/10.3991/ijep.v10i3.12361

[6] Cresswell, John W. (2014). Research Design: Qualitative, quantitative, and mixed methods approaches, fourth edition

[7] K. Y. S. Putri, Zulhamri Bin Abdullah, Elisabeth Nugrahaeni, Rachmat Darmawan, Latifa Latifa (2020) Learning Management Strategy of Communication Studies through Blended Learning in Higher Education https://doi.org/10.3991/ijim. v14i16.15725

[8] Satin, A. et W. Shastry. 1993. Échantillonnage statistique: un guide non mathématique Deuxième édition. Statistique Canada. 12-602F.

[9] Cochran, W.G. 1977. Sampling Techniques. John Wiley and Sons, New York. 1972. The Design of Sample Surveys. McGraw-Hill Series in Probability and Statistics, New York.

[10] Carmines E.G. Zeller R.A. (1988) "Reliability and validity assessment". Sage publications, Beverly Hills, London.

[11] Fabienne Midy. Validité et fiabilité des questionnaires d'évaluation de la qualité de vie: une étude appliquée aux accidents vasculaires cérébraux. [Rapport de recherche] Laboratoire d'analyse et de techniques économiques(LATEC). 1996, 38 p., Table, ref. bib.: 3 p. 1/4. ffhal-01526979. https://doi.org/10.21474/ijar01/4691

[12] Cronbach, L.J. Coefficient alpha and the internal structure of tests. Psychometrika 16, 297-334 (1951). https://doi.org/10.1007/bf02310555

[13] Gardner R.C. \& Mac Intyre P.D., « A student's contribution to second language learning »: Part I « cognitive variables » \& Part II « affective variables », Language teaching, Vol. 25, $\mathrm{n}^{\circ} 4$ \& vol.26, n 1 (1992-1993). Girard D. (sous la direction de), Choix et distribution des contenus dans les programmes de langues, Strasbourg, Conseil de l'Europe (1988). https://doi.org/10.1017/s0261444800000045

[14] Huart, t. (2006). développement et validation d'un questionnaire multicomponentiel de motivation scolaire. Mesure et évaluation en éducation, 29(2), 63-97

[15] Nunnally J.C. (1978), Psychometric Theory, 2e édition, McGraw-Hill, NY.

\section{Authors}

Lynda Ouchaouka is a digital learning manager teaching in the fields of sciences of education in Ecole Normale Supérieure de Casablanca, she is a $\mathrm{PhD}$ student in Faculty of sciences Ben M'sik, Hassan II University Casablanca, Department of Physics, laboratory of engineering and materials, Morocco, (lynda.ouchaouka@gmail. com). 
Zineb Laouina is a PhD student in Faculty of sciences Ben M'sik, Hassan II University Casablanca, Department of Physics, laboratory of engineering and materials, Morocco, (Laouina.zineb1@gmail.com)

Mohamed Moussetad is a PhD in Physics, professor of physics in the Department of Physic, laboratory of engineering and materials, Faculty of sciences Ben M'sik, Hassan II University, Casablanca, Morocco (m.moussetad@gmail.com).

Mohammed Talbi is a PhD in Sciences and Processes of Analysis from the University Pierre et Marie Curie of Paris. He is currently the Dean of the Faculty of Sciences Ben M'Sik at Hassan II University, Casablanca, Morocco since 2014, and the Director of the Observatory of Research in Didactics and University Pedagogy (ORDIPU), (talbi.ordipu@gmail.com).

Najat El Amrani is a PhD in Biology, Professor in the Department of Biology Hassan II University Casablanca, (najat_elamrani@hotmail.com).

M'hamed El Kouali is a $\mathrm{PhD}$ in Chemistry, head of Laboratory of analytical chemistry and physico-chemistry of materials Hassan II University Casablanca (m.elkouali@gmail.com).

Article submitted 2020-10-09. Resubmitted 2021-02-26. Final acceptance 2021-02-26. Final version published as submitted by the authors. 